Corrigendum

\title{
Corrigendum to "Effects of Arsenic Trioxide-Loaded PLGA Nanoparticles on Proliferation and Migration of Human Vascular Smooth Muscle Cells"
}

\author{
Susu Zhao, ${ }^{1}$ Zeqian Yu, ${ }^{2}$ Yifen Zhang, ${ }^{1}$ and Mei Lin ${ }^{3}{ }^{3}$ \\ ${ }^{1}$ Department of Pathology, Affiliated Hospital of Nanjing University of Chinese Medicine, 210029 Nanjing, China \\ ${ }^{2}$ Department of Hepatic-Biliary-Pancreatic Center, Zhongda Hospital, Southeast University, 210029 Nanjing, China \\ ${ }^{3}$ Clinical Laboratory, Taizhou People's Hospital, Affiliated Hospital of Nanjing University of Chinese Medicine, \\ 225300 Taizhou, China
}

Correspondence should be addressed to Mei Lin; 1_mei@163.com

Received 14 February 2021; Accepted 14 February 2021; Published 31 July 2021

Copyright (c) 2021 Susu Zhao et al. This is an open access article distributed under the Creative Commons Attribution License, which permits unrestricted use, distribution, and reproduction in any medium, provided the original work is properly cited.

In the article titled "Effects of Arsenic Trioxide-Loaded PLGA Nanoparticles on Proliferation and Migration of Human Vascular Smooth Muscle Cells" [1], the author's identified errors in the legends of Figures 4 and 5, where " $6 \mu \mathrm{mol} / \mathrm{L}$ " should be corrected to the $3 \mu \mathrm{mol} / \mathrm{L}$ group as follows:

Figure 4: Results of Transwell cell migration assay. ${ }^{*} P<0.05,{ }^{* *} P<0.01$, and ${ }^{* * *} P<0.001$, compared with the control group; ${ }^{\#} P<0.05$ and ${ }^{\# \#} P<0.01$, compared with the $1 \mu \mathrm{mol} / \mathrm{L}$ group; ${ }^{\&} P<0.05$, compared with the $3 \mu \mathrm{mol} / \mathrm{L}$ group.

Figure 5: Relative mRNA expression by RT-PCR. ${ }^{*} P<0.05,{ }^{* *} P<0.01$, and ${ }^{* * *} P<0.001$, compared with the control group; ${ }^{\#} P<0.05$ and ${ }^{\#} P<0.01$, compared with the $1 \mu \mathrm{mol} / \mathrm{L}$ group; ${ }^{\&} P<0.05$, compared with the $3 \mu \mathrm{mol} / \mathrm{L}$ group.

The authors apologize for this error and confirm that it does not affect the conclusions of the article.

\section{References}

[1] S. Zhao, Z. Yu, Y. Zhang, and M. Lin, "Effects of Arsenic Trioxide-Loaded PLGA Nanoparticles on Proliferation and Migration of Human Vascular Smooth Muscle Cells," Journal of Nanomaterials, vol. 2021, Article ID 5575370, 8 pages, 2021. 